\title{
Sola Gratia Melihat dari Status Manusia di Hadapan Allah, Karya Penebusan Kristus, dan Anugerah Yang Mendahului Keselamatan
}

\author{
Sola Gratia Looks at Man's Status before God, Christ's Redemptive Work, and Grace \\ Preceding Salvation
}

Josapat Bangun ${ }^{1}$, Juliman Harefa ${ }^{2}$

${ }^{1}$ Sekolah Tinggi Teologi Providensia Adonay Batu | josbangun203@gmail.com

2 STT Banua Niha Keriso Protestan Sundermann Nias| julimanh24@sttsundermann.ac.id

\section{ARTICLE INFO}

Submitted: November 15, 2020

Review: November 28, 2020

Accepted: December 31, 2020

Published: December 31, 2020

\section{KEYWORDS}

freedom, redemption, saved, sin, sola gratia

\section{CORESPONDENCE}

Phone : +62 81234417417

E-mail : josbangun203@gmail.com

\begin{abstract}
A B S T R A C T
To this day, there is still the view of a group of Christians who consider that human beings are saved not only by the grace of God alone. The reason for refusing salvation ultimately is grace because they believe that people have the ability and freedom to decide for themselves whether to accept or reject the salvation that God offers. The purpose of this study is to explain how sinners can be saved by grace through christ's redemptive work. The methodology used in this research is to use text analysis and literature studies. This article describes how sin has polluted all aspects of human life so that it has no good that can save itself. The freedom given by God to man is now shackled by sin so that man cannot choose and determine his salvation. Based on the results of text analysis and literature studies, it turns out that man is saved by God's grace, which provides a way out of the problem of sin most satisfyingly the demands of justice, righteousness, and holiness of God through and in christ's redemptive work. Christ's redemptive work is a gift to sinners based on grace and abundant grace. A man sinned before being saved and received God's grace in many forms and ways until he was saved. Sola gratia stated the man's lack of good and effort resulted in her being saved.
\end{abstract}

\section{A B S T R A K}

Hingga saat ini, masih ada pandangan sekelompok orang Kristen yang menganggap bahwa manusia diselamatkan tidak hanya oleh karena anugerah Tuhan semata. Alasan menolak keselamatan sepenuhnya adalah anugerah disebabkan karena mereka percaya bahwa manusia memiliki kemampuan dan kebebasan untuk menentukan sendiri apakah menerima atau menolak keselamatan yang ditawarkan Tuhan. Tujuan penelitian ini adalah untuk menjelaskan bagaimana manusia berdosa bisa diselamatkan berdasarkan anugerah melalui karya penebusan Kristus. Metodologi yang digunakan dalam penelitian ini adalah mengunakan analisis teks dan kajian pustaka. Artikel ini mendeskripsikan bagaimana dosa telah mencemari seluruh aspek kehidupan manusia sehingga tidak memiliki kebaikan yang dapat menyelamatkan dirinya. Kebebasan yang diberikan oleh Tuhan kepada manusia sekarang telah terbelenggu oleh dosa sehingga manusia tidak mempunyai kemampuan untuk memilih dan menentukan keselamatannya. Berdasarkan hasil analisis teks dan kajian pustaka, ternyata manusia diselamatkan oleh rahmat serta anugerah Allah yang menyediakan jalan keluar dari masalah dosa dengan cara yang paling memuaskan tuntutan keadilan, kebenaran, dan kesucian Allah melalui dan di dalam karya penebusan Kristus. Karya penebusan Kristus merupakan sebuah anugerah kepada manusia berdosa berdasarkan rahmat dan kasih karunia yang melimpah. Manusia berdosa sebelum diselamatkan sudah terlebih dahulu menerima anugerah Allah dalam berbagai bentuk dan cara sampai akhirnya dia diselamatkan. Sola gratia 
menyatakan tiadanya andil kebaikan dan usaha yang disumbangkan oleh manusia yang mengakibatkan dia diselamatkan.

Kata kunci: diselamatkan, dosa, kebebasan, penebusan, sola gratia

\section{PENDAHULUAN}

Doktrin sola gratia yang viral lebih dari lima abad lalu hingga kini masih terus dibicarakan di antara orang Kristen, khususnya dikalangan akademisi. Terdapat dua kelompok pandangan dalam memahami sola gratia. Kelompok pertama adalah mereka yang setuju dan menerima sola gratia sepenuhnya tanpa andil manusia. Dasar pemikiran kelompok ini adalah manusia setelah jatuh ke dalam dosa tidak mempunyai potensi sama sekali untuk menentukan dan memilih keselamatannya. Sola gratia, diberikan hanya di dalam dan melalui Yesus Kristus dan terbukti kebenarannya dalam Kitab Suci. ${ }^{1}$ Kelompok kedua adalah mereka yang setuju sola gratia tetapi ada andil manusia disumbangkan di dalamnya. Dasar pemikiran kelompok ini adalah walaupun manusia sudah jatuh ke dalam dosa dalam dirinya masih mempunyai kemampuan dan kebebasan untuk menentukan pilihannya atas keselamatannya. Walaupun Allah memiliki kedaulatan, itu tidak berarti menghilangkan kehendak bebas manusia, tetapi sebaliknya predestinasi jangan dipandang sebagai penolakan (overriding) terhadap kehendak bebas manusia. ${ }^{2}$ Jadi sola gratia bagi kelompok ini adalah "grace and freedom, calling and response."

Memperdamaikan kedua pandangan kelompok ini tentunya harus kembali ke dalam Alkitab sebagai standar kebenaran mutlak iman Kristen yang bersifat normatif, supaya menjadi

1 Paul O'Callaghan, "Luther and 'Sola Gratia': The Rapport Between Grace, Human Freedom, Good Works and Moral Life," Scripta Theologica 49, no. 1 (2017): 193-212,

https://revistas.unav.edu/index.php/scriptatheologica/article/view/8750.

${ }^{2}$ Murni H. Sitanggang, “Kehendak Bebas Manusia Menurut Augustine Dan Calvin Dalam Kaitannya Dengan Kedaulatan Allah," Jurnal Teologi Gracia Deo 1, no. 1 (2018): 32-45, http://www.sttbaptisjkt.ac.id/ejournal/index.php/graciadeo/article/view/20.

${ }^{3} \mathrm{O}$ 'Callaghan, "Luther and 'Sola Gratia': The Rapport Between Grace, Human Freedom, Good Works and Moral Life." dasar argumentasi yang lebih logis dan konsisten. Doktrin sola gratia akan cenderung salah dipahami jika terlalu tinggi menempatkan kemampuan, kebebasan, dan otonomi manusia yang sudah berdosa dalam menggunakan kehendak bebasnya ketika menentukan pilihan keselamatannya. Doktrin sola gratia pertamatama harus dipahami dalam perspektif doktrin antropologi dan hamartologi. Mengapa demikian? karena pembahasan doktrin soteriologi tidak bisa dipisahkan dari doktrin antropologi dan hamartologi.

Martin Luther ketika menulis buku berjudul "De Servo Arbitrio/Bondage of the Will" merupakan bentuk perlawanan terhadap tulisan Desiderius Erasmus seorang humanis yang berjudul "De Libero Arbitrio Diatribe Sive Collatio/ Discourse Concerning Free Will". Bagi Luther "man's free will" setelah jatuh ke dalam dosa diperbudak oleh dosa. ${ }^{4}$ John Calvin berpandangan bahwa seseorang tidak mungkin menemukan kebenaran rohani di dalam sendiri karena dia telah dirusak oleh dosa dan mati dalam dosa. Pandangan Calvin ini sangat dipengaruhi Alkitab dan Bapa Gereja Agustinus. Agustinus mengatakan bahwa kebebasan manusia telah dibelenggu dan diperbudak oleh dosa. ${ }^{5}$ Paulus memandang bahwa manusia bukan hanya diperbudak oleh dosa tetapi juga diperbudak oleh Iblis. ${ }^{6}$

${ }^{4}$ Jean-Marc Berthoud, "Luther and Erasmus: The Central Confrontation of the Reformation," Unio Cum Christo 3, no. 1 (April 1, 2017): 65-81, https://uniocc.com/archive/luther-and-erasmus.

${ }^{5}$ Garry J. Williams, "The Five Solas of the Reformation: Then and Now," Unio Cum Christo 3, no. 1 (April 1, 2017): 13,

https:// uniocc.com/archive/47-the-five-solas-ofthe-reformation-then-and-now.

6 Sulastio Hari, "Keselamatan Karena Kasih Karunia Menurut Efesus 2:1-10" 6, no. 1 (2020): 3245, https://sttintheos.ac.id/ejournal/index.php/antusias/article/view/307/17 8. 
Paulus dalam pandangannya tentang antropologi, hamartologi, dan soteriologi menempatkan manusia sebagai ciptaan yang sudah berdosa yang hanya mungkin diselamatkan oleh anugerah. Paulus mengajarkan kepada jemaat di Roma bahwa semua orang telah berdosa dan kehilangan kemuliaan Allah (Rm. 3:23). Upah dosa ialah maut, sehingga manusia diselamatkan hanya karena kasih karunia Allah (Rm 6:23). Paulus juga menyampaikan kepada jemaat Kristen di Efesus bahwa mereka semua telah mati karena pelanggaran dan dosa mereka (Ef. 2:1, 5). Sekarang mereka hidup bersama Kristus bukan karena terdapat usaha yang mereka sumbangkan, karena dosa menyebabkan mereka semua telah mati dalam dosa. Tuhan yang berdaulat menghembuskan nafas hidup kepada mereka sehingga mereka dapat memperoleh hidup baru dalam Kristus. Jemaat Efesus diselamatkan hanya oleh anugerah Tuhan bukan karena perbuatan dan usaha mereka, (Ef. 2:8-9). Paulus menggambarkan keselamatan sebagai tindakan penciptaan baru di dalam Kristus Yesus, (Ef. 2:10). Mereka diciptakan kembali oleh karya Roh Allah yang penuh karunia, semua pekerjaan itu disebut dengan istilah sola gatia.

Artikel ini bertujuan menempatkan doktrin sola gratia sebagai penyebab utama manusia diselamatkan, oleh karena Alkitab secara konsisten mengajarkan demikian. Doktrin sola gratia masih tetap relevan dipercakapkan dan direfleksikan dalam kehidupan orang percaya di era pascamodernisme. Gereja dalam segala aktivitas kehidupan pribadi, pelayanan, doktrin, liturgi, dan ibadah harus dibangun berdasarkan pengajaran Alkitab dan berfokus kepada Kristus, semua itu dimulai dari sola gratia.

Keterbaruan penelitian ini berfokus pada sola gratia dengan melihat aspek antropologi, hamartologi, dan soteriologi dalam bingkai pemikiran Alkitab. Hasil penelitian ini diharapkan menjadi nilai tambah khazanah pengetahuan teologi dalam bidang antropologi dan hamartologi. Lebih lanjut lagi, hasil penelitian ini dapat digunakan sebagai referensi tambahan bagi pengembangan, pembahasan, dan penerapan doktrin sola gratia dalam

7 Nana Syaodih Sukmadinata, Metode Penelitian Pendidikan (Bandung: PT Remaja Rosdakarya, 2015), 60. lingkungan akademik serta gereja. Selain itu, hasil penelitian ini juga secara praktis bermanfaat sebagai rujukan bagi pendidik dan rohaniawan dalam melakukan pembinaan warga gereja (katekisasi, kelompok sel, dan pendalaman iman).

\section{METODE}

Penelitian ini ditulis menggunakan pendekatan kualitatif dengan melakukan analisis teks dan kajian pustaka. Mendeskripsikan dan menganalisis pemikiran individu maupun kelompok melalui kajian literatur, ${ }^{7}$ lalu membandingkan dengan teks-teks yang terdapat dalam Alkitab secara eksplisit maupun implisit yang berkaitan dengan konsep sola gratia. Terdapat tiga hal penting yang akan dijelaskan, pertama sola gratia dilihat dari status manusia berdosa di hadapan Tuhan. Kedua sola gratia bergantung sepenuhnya pada karya penebusan Kristus di kayu salib. Ketiga gratia Theo mendahului keselamatan manusia yang diberikan Allah kepada manusia dalam berbagai cara dan bentuk, baik berupa common grace maupun special grace.

\section{HASIL DAN PEMBAHASAN}

\section{Status Manusia di Hadapan Tuhan Sebelum Diselamatkan}

\section{Manusia Mati di hadapan Allah}

Doktrin antropologi Kristen menempatkan manusia sebagai ciptaan Tuhan yang pada awalnya sungguh amat baik (Kej. 1:31); namun setelah manusia jatuh ke dalam dosa kondisi manusia semua rusak dan penuh kekerasan (Kej. 6:11); dosa menyebabkan manusia telah kehilangan kemuliaan Allah (Rm. 3:23); ganjaran yang diberikan Allah atas dosa manusia adalah maut (Rm. 6:23); sekarang kondisi manusia mati oleh karena pelangaran dan dosa mereka (Ef. 2:1). Dosa adalah penjelasan yang lebih komprehensif tentang kejahatan manusia, melakukan pelanggaran dalam keadaan berdosa yang akan mendatangkan hukuman Allah. ${ }^{8}$ Itu berarti bahwa manusia sudah kehilangan segala kemampuannya untuk menyelamatkan dirinya melalui usaha dan perbuatannya.

8 Toni Merida, Christ-Centered Exposition Commentary (Nashville, Tennessee: B\&H

Publishing Group, 2014), 43. 
"Manusia dengan kejatuhannya ke dalam keadaan berdosa, secara keseluruhan kehilangan segenap kemampuan untuk menghendaki kebaikan rohani apa pun yang menyertai keselamatan, sehingga sebagai manusia yang alamiah, yang secara keseluruhan tidak menghendaki yang baik, dan mati di dalam dosa, dia dengan kekuatan sendiri tidak memiliki kemampuan untuk mengubah dirinya." 9

Manusia yang sudah mati dalam dosa pasti tidak mempunyai kemampuan apa-apa lagi untuk mengubah hidupnya dan berbuat baik sesuai standar kebenaran Allah guna menyelamatkan hidupnya (Kol. 2:13).

\section{Manusia adalah Hamba Dosa}

Manusia setelah jatuh ke dalam dosa adalah hamba dosa, diperbudak oleh dosa, berbuat dosa, dan hidup dalam dosa (Yoh. 8:34). Dosa yang berkuasa, memerintah, mengatur, mengendalikan hidup manusia sehingga tidak berdaya olehnya. Manusia yang tawanan oleh dosa tidak berdaya atas dirinya sendiri sehingga menjadi pelayan dosa ( $\mathrm{Rm}$. 7:23). Luther dan Calvin menekankan fakta bahwa: "Fallen man is now in bondage to sin, and therefore has lost his true freedom." 10 Dosa menguasai manusia sehingga tidak mempunyai kebebasan untuk melakukan kebenaran Allah dari dirinya yang memungkinkan dia diselamatkan karena dibelenggu oleh kuasa dosa (Rm. 6: 18, 20). Manusia yang diperbudak oleh dosa takluk dibawah kuasa dosa seperti orang yang dibelenggu oleh rantai yang kuat, dia tidak akan pernah mampu melepaskan diri sendiri. Harus ada kekuatan dari luar dirinya untuk membuka, melepaskan, dan membebaskan belenggu yang mengikat dirinya selama ini.

\section{Manusia Lemah dan Tidak Berdaya}

Fakta dan realita membuktikan bahwa manusia mempunyai banyak kelemahan dan keterbatasan dari dalam dirinya setelah jatuh ke dalam dosa. Paulus berkata: “Karena waktu kita

${ }^{9}$ G. I. Williamson, Pengakuan Iman

Westminster (Surabaya: Penerbit Momentum, 2017), 129.

10 Anthony A. Hoekema, Created in God's Image (Michigan: William B. Eermands Publishing Company, 1994), 133. masih lemah, Kristus telah mati untuk kita orang-orang durhaka." (Rm. 5:6). Kata Yunani "asthenes" artinya "lemah, sakit, tidak mempunyai kekuatan, tidak bertenaga, tidak mempunyai kemampuan, tidak berkuasa."11 Lemah tidak berdaya seperti seorang yang sedang koma di ruang Intensive Care Unit (ICU), dirinya tidak mampu sama sekali mengupayakan kesembuhan dengan segala daya dan upaya dari dalam dirinya sendiri. Kesembuhan dan kelangsungan hidupnya sangat bergantung pada peralatan medis dan pengobatan yang dilakukan.

Manusia berdosa kondisinya lemah tidak berdaya karena dikuasai dan diperbudak oleh dosa seringkali diwujudkan dalam keinginankeinginan dan perbuatan daging. Keinginan daging dalam teologi Paulus adalah menyatakan totalitas manusia yang sudah jatuh ke dalam dosa. Manusia dikuasai, diperintah, dan diperbudak oleh keinginan daging. Keinginan daging memakai dan memperalat tubuh manusia untuk melakukan keinginannya yang bertentangan dengan keinginan Roh Kudus, yang mengakibatkan manusia tidak berdaya sama sekali sehingga tidak mampu melakukan apa yang dia kehendaki (Gal. 5:17-21).

Paulus dalam pengalaman hidupnya mengatakan "Sebab aku tahu, bahwa di dalam aku, yaitu di dalam aku sebagai manusia, tidak ada sesuatu yang baik. Sebab kehendak memang ada di dalam aku, tetapi bukan hal berbuat apa yang baik. Sebab bukan apa yang aku kehendaki, yaitu yang baik, yang aku perbuat, melainkan apa yang tidak aku kehendaki, yaitu yang jahat, yang aku perbuat" (Rm 7:18-19). Orang lemah sama sekali tidak berdaya untuk mengupayakan keselamatannya melalui segala usahanya. Roh Tuhan yang memberikan kekuatan kepada yang lelah dan menambah semangat kepada yang tidak berdaya (Yes. 40:29).

\section{Manusia "Dikuasai" Iblis}

Orang-orang percaya di Efesus sebelum hidup di dalam Kristus mengikuti dan mentaati

11 Spiros Sodhiates, The Hebrew-Greek Key Study Bible, New American Standard Version (Chattanooga: AMG Publishers, 1990), 1813. 
penguasa kerajaan angkasa, yaitu roh yang sekarang sedang bekerja di antara orang-orang durhaka (Ef. 2:2). Michael Stoltzfus berkata: "that their will are bound to Satan and have no inkling to anything but selfish motives. There is no space for free will in Luther's theology because the human will is held in complete bondage of Satan."12 Manusia yang sudah jatuh ke dalam dosa sering kali terikat oleh keinginan-keinginan yang jahat sehingga tidak mempunyai kemampuan mengusahakan dan melakukan apa yang benar di hadapan Tuhan. Manusia berada dibawah bayang-bayang kuasa setan yang bekerja siang malam untuk menghalangi manusia supaya tidak bisa datang kepada Kristus (1 Ptr. 5:8).

Paulus dan rekan sekerjanya sering diganggu oleh Iblis dan roh-roh jahat dalam perjalanan misi dan rencana mengunjungi jemaat, bahkan Paulus sendiri lebih dari sekali dihalang-halangi oleh Iblis dalam rencananya datang ke jemaat di Tesalonika (1 Tes. 2:18). Gereja harus berjuang melawan penguasa, penghulu, roh jahat di udara, (Ef. 6:12). Terjadi perang global antara Kristus dan kerajaan kegelapan, gereja harus ikut berperang bersama Kristus melawan roh-roh jahat dengan menggunakan seluruh perlengkapan senjata Allah dan memakai kebenaran Alkitab untuk melawan segala kepalsuan serta tipu muslihat Setan. Manusia berdosa yang dijerat dan dikuasai Iblis harus disadarkan supaya mereka terlepas dari jerat Iblis yang telah mengikat mereka pada kehendaknya (2 Tim. 2:26).

\section{Pikiran Manusia Dibutakan oleh Ilah Zaman Ini}

Orang yang tidak percaya kepada Kristus pikirannya telah dibutakan oleh ilah zaman ini (2 Kor. 4:4). Siapakah "ilah zaman ini" yang membutakan orang-orang yang belum percaya? Orang Kristen mula-mula menggunakan bahasa seperti itu untuk Iblis (Yoh. 12:31; 14:30; 16:11). Kebanyakan sarjana modern menyimpulkan Iblis mempunyai kemampuan dan kuasa untuk mempengaruhi hati dan pikiran manusia sehingga tidak dapat melihat cahaya Injil. ${ }^{13}$ Ilah zaman dalam konteks saat itu adalah dewa-dewi yang disembah oleh orang-orang di sekitar Asia Kecil dan wilayah sekitarnya. Ilah zaman juga

12 Michael Stoltzfus, "Martin Luther: A Pure Doctrine of Faith," Journal of Lutheran Ethics 3, no. 1 (2003), https:// www.elca.org/JLE/Articles/898. termasuk di dalamnya roh-roh jahat penguasa kerajaan angkasa yang bekerja siang malam menghalangi dan mencegah orang datang kepada Kristus (Ef. 6:12).

Paulus memandang orang yang tidak percaya, hidup dalam kancah dosa dan menjadi pemuja setan, hati serta pikiran mereka dibutakan oleh ilah zaman ini. Orang yang sudah buta secara rohani tidak akan mampu melihat jalan keselamatan. Orang buta tidak bisa menuntun dirinya sendiri untuk datang kepada Kristus. Orang buta menuntun orang buta keduanya akan terjerumus ke dalam jurang kebinasaan, (Mat. 15:14). John Newton penulis lagu Amazing grace mengatakan: "That saved a wretch like me, I once was lost, but now I'm found, was blind, but now I see". Dirinya yang keji, terkutuk, hilang, buta, dan hina kembali dapat melihat karena diselamatkan oleh anugerah Tuhan.

\section{Manusia Tidak Mencari dan Datang Kepada Allah}

Raja Daud ribuan tahun lalu menulis mazmur: "... apakah ada yang mencari Allah. Mereka semua telah menyeleweng, semuanya telah bejat; tidak ada yang berbuat baik, seorangpun tidak." (Mzm. 14:1-3). Paulus berkata: "tidak ada seorangpun yang mencari Allah." (Rm. 3:11). Manusia yang sudah mati karena dosa tidak bisa datang sendiri kepada Allah, harus ada intervensi Ilahi, "Tidak ada seorangpun yang dapat datang kepada-Ku, jikalau ia tidak ditarik oleh Bapa dan kalau Bapa tidak mengaruniakannya kepadanya." (Yoh. 6:44, 65). Manusia tidak ada yang mencari dan menginginkan Allah dalam hidupnya sebab mereka semua sudah rusak dan bejat karena dosa. Allah yang berinisiatif, berencana, dan bertindak mencari manusia karena kasih-Nya.

Alkitab mengajarkan bahwa manusia sejak jatuh ke dalam dosa keadaannya rusak total dan kehilangan semua kemampuan untuk melakukan kebaikan rohani. Manusia tidak mampu dengan kekuatannya sendiri untuk mempertobatkan hidupnya. Manusia sebelum diselamatkan oleh anugerah status dan kondisinya setelah jatuh ke dalam dosa sepenuhnya tidak berdaya, tidak mampu, tidak

13 Ben Witherington III, The New Cambridge Bible Commentary (Edinburgh: Cambridge University Press, 2005), 173. 
dapat menyelamatkan dirinya sendiri; dengan demikian manusia diselamatkan oleh Kristus sepenuhnya berdasarkan sola gratia.

\section{Karya Penebusan Tuhan Yesus Kristus}

Redemptive work of Christ adalah satusatunya jalan yang memungkinkan manusia diselamatkan, karya itu merupakan anugerah Allah kepada manusia berdosa. Karya penebusan Kristus disediakan oleh Allah sendiri dengan mengutus Anak-Nya yang tunggal ke dalam dunia (Yoh. 3:16). Anak Allah mengurbankan diri-Nya untuk menjadi tebusan bagi banyak orang (Mrk.10:45). Kristus dikurbankan untuk menebus manusia dari dosa, kematian, hukuman, dan murka Allah yang akan datang. Allah menghukum dosa manusia di dalam tubuh Kristus di kayu salib (Rm. 8:1-3). ${ }^{14}$ Karya penebusan yang dikerjakan oleh Tuhan Yesus sifatnya menggantikan, memperdamaikan, dan memulihkan hidup manusia dengan Allah.

\section{Pengurbanan}

Selama berabad-abad, karya Kristus telah dikaitkan dengan kata 'atonement'. Makna kata ini adalah membawa orang berdosa kembali ke dalam persekutuan dengan Kristus. Istilah yang mengungkapkan hubungan antar pribadi yang rusak terjadi rekonsiliasi karena adanya pengampunan. ${ }^{15}$ Kristus dikurbankan untuk penebusan manusia berdosa, (Mat. 20:28). Kurban Kristus adalah kurban pengampunan dosa manusia. Luther mengatakan: “Christ's sacrifice for us is the only basis of our being forgiven, fully, and perfectly and once for all."16 Kristus mencurahkan darah-Nya untuk menebus manusia dari dosa dan cara hidup yang sia-sia, manusia yang seharusnya dihukum karena dosanya sekarang dibebaskan karena Kristus telah memikul dosa mereka di kayu salib, (1 Pet.1:19; 2:24).

${ }^{14}$ Robert S. Paul, The Atonement and the Sacraments: The Relation of the Atonement to the Sacraments of Baptism and the Lord's Supper (Nashville: Abingdong Press, 1960), 18-19.

${ }^{15}$ Ubong Ekpenyong Eyo, "The Concept of Atonement in the Old Testament, Greco-Roman World and the New Testament," Journal of Humanities and Social Sciences 2, no. 2 (2020): 75-81.

\section{Perdamaian}

Propitiation artinya "meneduhkan, menghentikan, menenangkan" murka Allah terhadap dosa manusia, akibatnya terjadi perdamaian karna kurban Kristus memuaskan dan berkenan kepada Allah. ${ }^{17}$ Kurban Kristus di kayu salib menghasilkan perdamaian antara Allah dan manusia. Kristus yang mati di atas kayu salib meredakan dan menghentikan murka Allah atas dosa manusia, hal ini menyebabkan terbuka jalan bagi manusia untuk diterima kembali ke dalam persekutuan kasih dengan diri Allah. Tuhan Yesus Kristus Juru damai antara Allah dan manusia, maka sekarang ada damai dengan Allah karena murka-Nya sudah tenang, teduh, dan berhenti karena karya perdamaian Kristus (Rm. 5:10).

\section{Rekonsiliasi}

Manusia karena pemberontakannya menjadi musuh Allah dan berada dibawah murka Allah (Kol. 1:21; Rm. 1:18). Bukan hanya itu saja, manusia berdosa juga kondisinya rusak dan terpisah jauh dari hadirat Allah tetapi melalui pengurbanan Kristus relasi manusia dipulihkan kembali dengan Allah (Ef. 2:13). Rekonsiliasi adalah karya Kristus yang membawa keselamatan bagi manusia. Kristus datang untuk membawa manusia kembali kepada Tuhan. Kristus berkurban untuk memulihkan hubungan manusia dengan Allah yang rusak karena dosa, (Ef. 2:14-16; 2 Kor. 5:19). Kurban Kristus memulihkan persekutuan manusia dengan Allah, rekonsiliasi antara Allah dan manusia terjadi oleh karna darah Kristus dicurahkan di kayu salib (Rm. 5:6-11; 8:5).

\section{Menggantikan}

Manusia karena dosanya harus dihukum mati di masa yang akan datang tetapi Kristus mati untuk menanggung dan menggantikan hukuman manusia melalui pengurbanan-Nya.

${ }^{16}$ Howard Griffith, "Luther in 1520:

Justification by Faith Alone," Reformed Faith $\mathcal{E}$ Practice 3, no. 1 (2018): 28-37,

https://journal.rts.edu/article/luther-in-1520justification-by-faith-alone/.

${ }^{17}$ Anna Nicholes, "Diligence : Journal of the Liberty University Online Religion Capstone in Research and Scholarship The Foundation of New Testament Canonicity” 1, no. September (2016). 
Kurban Kristus yang sempurna memuaskan tuntutan keadilan, kebenaran, dan kesucian Allah, (Rm. 5:6; 5:8). Kristus berkurban untuk menggantikan hukuman manusia karena kasih Allah yang sangat besar kepada manusia berdosa, (Yoh. 3:16). Melalui pengurbanan Kristus di atas kayu salib manusia diterima kembali dalam persekutuan dengan Allah sebagai anak-anak-Nya (Yoh. 1:12).

\section{SOLA GRATIA}

Sola adalah konsep Alkitab yang berkaitan dengan keselamatan manusia. Sola gratia sudah ada dalam Alkitab dan secara khusus dalam tulisan-tulisan Paulus. Reformator merumuskan kembali doktrin sola gratia dari Alkitab di dalam situasi gereja yang sedang dilanda krisis teologi, spiritual, dan moral yang rusak parah. Reformator berteologi dalam konteks zaman untuk menjawab tantangan kehidupan saat itu. Sola gratia adalah karya Allah Tritunggal dan unsur-unsur anugerah Allah lainnya yang tercakup di dalamnya.

\section{Karya Allah Bapa}

Sola gratia adalah karya Allah Bapa yang menetapkan keselamatan manusia di dalam kekekalan, hal ini sering disebut dengan istilah "God's decreed will." Allah telah memilih dan menentukan orang percaya sesuai dengan kerelaan kehendak-Nya di dalam kekekalan sebelum manusia ada (Ef. 1:4-5). Segala sesuatu bekerja menurut keputusan kehendak Allah yang berdaulat yang tidak bisa dibatalkan oleh manusia (Ef. 1:11). Allah sang Pencipta memiliki rencana kekal berdasarkan kebijaksanaan-Nya untuk kebaikan ciptaan-Nya. Allah berkarya dalam ciptaan-Nya guna mewujudkan rencana ini. Rencana Allah ini mengatur dan mengendalikan semua yang terjadi dalam dunia, dari peristiwa paling signifikan dalam sejarah hingga peristiwa yang tampaknya terjadi secara kebetulan yang tidak disadari serta dipahami dengan logika. Semua itu jika diperhatikan dengan cermat dalam terang firman Tuhan, sebenarnya Tuhan memiliki rencana dan tujuan yang sempurna dalam segala sesuatu (Rm. 8:28).

18 Martin M. Davis, “T.F. Torrance: Union with Christ through the Communion of the Spirit," In die Skriflig/In Luce Verbi 51, no. 1 (2017): 1-9.

\section{Karya Tuhan Yesus Kristus}

Sola gratia juga adalah karya Tuhan Yesus Kristus yang melakukan dan menggenapi apa yang telah ditetapkan oleh Bapa di dalam sejarah manusia (Yoh. 12:27). Yesus berkata: "Karena Anak Manusia juga datang bukan untuk dilayani, melainkan untuk melayani dan untuk memberikan nyawa-Nya menjadi tebusan bagi banyak orang." (Mrk. 10:45). Kristus Yesus menebus dan mengampuni dosa manusia dengan darah-Nya. Rasul Paulus mengatakan: "Sebab di dalam Dia dan oleh darah-Nya kita beroleh penebusan, yaitu pengampunan dosa, menurut kekayaan kasih karunia-Nya, yang dilimpahkan-Nya kepada kita dalam segala hikmat dan pengertian." (Ef.1:7-8). Penebusan Kristus memungkinkan manusia diterima kembali ke dalam persekutuan dengan Allah, karena telah terjadi rekonsiliasi berdasarkan pengampunan dosa. ${ }^{18}$

\section{Karya Allah Roh Kudus}

Roh Kudus melalui karya-Nya yang bersifat evangelistis terlibat aktif mengaplikasikan karya pengurbanan Kristus pada masa lampau sehingga tetap aktual sepanjang zaman. Roh Kudus "mentransfer" karya pengurbanan Kristus di atas kayu salib sehingga menjadi pengalaman nyata pada masa kini. Keselamatan menjadi terwujud dalam kehidupan seseorang oleh karena Roh Kudus sebagai Penciptanya. Yesus berkata: "Aku berkata kepadamu, sesungguhnya jika seseorang tidak dilahirkan dari air dan Roh, ia tidak dapat masuk ke dalam Kerajaan Allah", (Yoh. 3:5). Roh Kudus juga yang memeteraikan setiap orang yang sudah lahir baru menjadi milik Kristus, (Ef. 1:13; 4:30). Setelah manusia diselamatkan karena anugerah atau sola gratia, dia dikuduskan dari statusnya sebagai orang berdosa (sinner) dan juga dari segala perbuatan dosa (sins). Sebagai orang Suci (status baru) di dalam Kristus, dia juga harus terus giat serta berjuang memelihara kesucian hidup melalui dan di dalam anugerah Tuhan. Manusia yang telah dipilih-Nya akan dipanggil, diregenerasi oleh Roh Kudus, dibenarkan oleh Kristus, dikuduskan, dan pada akhirnya nanti orang-orang yang sudah diselamatkan oleh anugerah akan dimuliakan-Nya. Semua ini 
adalah karya Allah semata-mata, tanpa campur tangan manusia (Rm. 8:29-30). ${ }^{19}$

\section{Injil Keselamatan}

Orang-orang yang sudah diselamatkan karena anugerah diberi mandat oleh Kristus supaya memberitakan Injil keselamatan kepada dunia yang menuju kebinasaan (Mat. 28:19-20). Injil Kristus harus diberitakan supaya manusia yang mendengarnya diselamatkan. Paulus mengatakan: "Sebab aku mempunyai keyakinan yang kokoh dalam Injil, karena Injil adalah kekuatan Allah yang menyelamatkan setiap orang yang percaya" (Rm. 1:16). Injil Kristus mempunyai kuasa untuk menyelamatkan manusia berdosa ketika diberitakan dengan kuasa Roh Kudus dan dalam kebenaran. "Sebab Injil yang kami beritakan bukan disampaikan kepada kamu dengan kata-kata saja, tetapi juga dengan kekuatan oleh Roh Kudus dan dengan suatu kepastian yang kokoh." (1 Tes. 1:5). Sekarang jelaslah pemberitaan Injil Yesus Kristus memungkinkan orang yang mendengarkannya dapat diselamatkan dan menjadi milik Tuhan Yesus Kristus (Rm. 10:14-15).

\section{Rahmat Allah}

Allah memiliki rahmat atau belas kasihan yang besar kepada manusia yang belum diselamatkan. Paulus berkata: "Allah yang kaya dengan rahmat, oleh karena kasih-Nya yang besar, yang dilimpahkan-Nya kepada kita" (Ef. 2:4). Kata Yunani "eleos" artinya rahmat atau belas kasihan Allah terhadap situasi kehidupan manusia dalam penderitaan. Belas kasihan Allah mendorong Dia bertindak positif untuk melakukan kebaikan terhadap orang-orang sengsara dan menderita dalam dosa. Rahmat atau belas kasihan Allah begitu besar kepada dunia yang binasa karena dosa. ${ }^{20}$ Rahmat atau belas kasihan Allah kepada dunia begitu besar sehingga Ia mengaruniakan Anak Tunggal-Nya ke dalam dunia supaya setiap orang yang percaya kepada-Nya tidak binasa, melainkan

${ }^{19}$ Gregorius Handoyo Suwito, “Karya Allah Dalam Menjamin Keselamatan Orang Percaya Dalam Perjanjian Baru," Teologi dan Pengembangan Pelayanan (2017): 16-43.

${ }^{20}$ Sodhiates, The Hebrew-Greek Key Study Bible, New American Standard Version, 1831. beroleh hidup yang kekal (Yoh. 3:16). Kehadiran Anak Allah ke dalam dunia dan mati untuk menebus orang berdosa menyatakan kemurahan Allah Sang Juruselamat dan kasih-Nya kepada manusia. (Titus. 3:4). Rahmat atau belas kasihan Allah tidak menginginkan orang yang dikasihiNya binasa. Kasih Allah selalu menginginkan orang yang dikasihi-Nya hidup selama-lamanya bersama-Nya dalam kekekalan.

\section{Melalui Iman}

Iman bersifat supernatural bukan natural, artinya iman itu pemberitaan Allah kepada manusia dengan maksud supaya dia dapat percaya kepada Tuhan Yesus Kristus. "Sebab kepada kamu dikaruniakan bukan hanya untuk percaya ...," (Flp.1:29). Manusia dapat percaya kepada Kristus karena dikaruniakan iman oleh Tuhan. Sola fide artinya "only by the faith bestowed upon them for the sake of Christ by the Holy Spirit and through the means of grace." 21 Ted Peters berkata: "the Holy Spirit makes present Jesus Christ", artinya manusia berdosa dimampukan menerima anugerah keselamatan melalui dan di dalam Kristus dengan iman oleh karena karya Roh Kudus. ${ }^{22}$

\section{Anugerah Mendahului Keselamatan Manusia}

Telah dijelaskan sebelumnya bahwa status manusia adalah orang berdosa di hadapan Allah yang secara total tidak mampu mengupayakan keselamatannya dengan cara apa pun. Keselamatan diberikan Allah bersifat satu arah, sering disebut dengan istilah Monergism karena merupakan pekerjaan tunggal Allah melalui karya Roh Kudus. Berbeda dengan pandangan Synergism yang bersifat dua arah, dimana keselamatan itu terjadi karena anugerah Allah dan respon manusia. Lalu bagaimana peran anugerah sebelum manusia diselamatkan? Apakah anugerah keselamatan hanya diterima oleh manusia ketika diselamatkan? Ataukah manusia sudah terlebih dahulu menerima anugerah Allah dalam berbagai bentuk dan cara

${ }^{21}$ Karl E. Hohmer, "Sola Gratia-Sola FideSola Scriptura," Logia: A Journal of Lutheran Theology 27, no. 3 (2018): 19-22.

${ }^{22}$ Ted Peters, "The Resistance of SelfJustification to God's Grace," Currents in Theology and Mission 46, no. 1 (2019): 58-68,

http://currentsjournal.org/index.php/currents/a rticle/view/166. 
mendahului keselamatan sebelum manusia diselamatkan? Allah memberikan anugerah terlebih dahulu kepada manusia dalam berbagai cara dan berbagai bentuk mendahului manusia diselamatkan (bdk. Ibr. 1:1) Salah satu poin dari TULIP adalah "irresistible of grace", artinya anugerah yang diberikan oleh Allah sebelum manusia diselamatkan tidak dapat ditolak oleh manusia. Anugerah diberikan dan diterima oleh manusia terus bekerja sampai akhirnya dia menerima secara total keselamatan pada saat lahir baru, semunya itu adalah anugerah Allah. Agustinus memberikan pengertian tentang anugerah sebagai berikut: "Grace is totally the work of God without any contribution from humans since humans can only will and do what is evil due to their fallen state"23 Jadi dapat dikatakan bahwa anugerah mendahului:

\section{Iman}

Orang percaya sering merasa bahwa karena dia percaya maka dia diselamatkan, ayat yang menjadi pendukung argunementasi tersebut adalah Yohanes 3:16, benarkah demikian? Jika diamati ayat tersebut, maka sebenarnya terdapat anugerah yang diberikan sebelumnya yaitu Allah mengasihi dunia ini sehingga Dia mengaruniakan Anak-Nya yang tunggal. Manusia bisa percaya kepada Kristus selalu didahului oleh pemberian anugerah kepada manusia, jadi anugerah yang menyebabkan manusia bisa percaya kepada Allah. Secara teologis dapat dikatakan bahwa bukan karena manusia percaya maka dia diselamatkan tetapi karena dia diselamatkan oleh anugerah terlebih dahulu maka dia percaya. Sebelum terjadi pengakuan "aku percaya" sudah terjadi karya Roh Kudus dalam hidup seseorang yang menyebabkan dia percaya. Aku percaya bukan penyebab tunggal manusia diselamatkan, pengakuan percaya lebih kepada proklamasi kepada dunia bahwa sudah terjadi keselamatan pada saat lahir baru melalui karya Roh Kudus.

Alkitab menyatakan fakta bahwa manusia pada dasarnya tidak memiliki iman dari dalam dirinya sendiri sehingga mereka diselamatkan

${ }^{23}$ Hans Harmakaputra, "Grace, the Holy Spirit, and Love: Comparing the Thoughts of St. Agustine, Peter Lombard, and William of St. Thierry," Jurnal Teologi Reformed Indonesia 7, no. 1 (2017): 33-41.
(Rm. 10:14). Tuhan saja yang mengaruniakan iman kepada manusia supaya dia sanggup menerima keselamatan yang dianugerahkan (Flp. 1:29). Luther menegaskan bahwa iman itu "seratus persen adalah anugerah dan pekerjaan Allah dalam hidup manusia." 24

\section{Perbuatan}

Manusia setelah jatuh ke dalam seluruh aspek hidupnya sudah tercemar oleh dosa. Segala bentuk kebaikan manusia tidak memungkinkan dia diselamatkan karena segala kebaikan yang dihasilkan dari dalam dirinya berasal dari hati dan pikiran yang berdosa. Segala kebaikan manusia najis dan bahkan segala kesalehannya seperti kain kotor (Yes 64:6). Agustinus berkata: "This grace, however, of Christ, without which neither infants nor adults can be saved, is not rendered for any merits, but is given gratis, on account of which it is also called grace." 25

Manusia tidak mempunyai investasi kebaikan yang menyebabkan dia berhak mendapatkan atau menerima keselamatan, karena itu keselamatan sepenuhnya adalah anugerah Allah (Ef. 2:8-9). Jadi, bukan karena aku berbuat baik maka aku diselamatkan tetapi karena aku sudah diselamatkan oleh anugerah maka aku berbuat baik; berbuat baik bukan supaya selamat tetapi karena sudah diselamatkan oleh anugerah. Perlu diperhatikan lebih lanjut dalam teologi Paulus mengenai aspek indikatif dan aspek imperatif. Aspek indikatif artinya sesuatu yang sudah terjadi dalam hidup orang percaya karena pekerjaan Allah tanpa jasa manusia, misalnya diselamatkan, ditebus, dibenarkan, dikuduskan, diperdamaikan, dst; sedangkan aspek imperatif adalah perintah Allah kepada orang percaya supaya mengaplikasikan, mengisi, dan mengerjakan apa yang sudah dikerjakan oleh Allah berdasarkan anugerah dalam kehidupan mereka. Orang percaya harus mengampuni, berdamai, mengasihi, hidup dalam damai sejahtera dengan semua orang, serta mematikan segala sesuatu yang duniawi, dan seterusnya.

24 Yakub B. Susabda, Pengantar Ke Dadalm Teologi Reformed (Surabaya: Lembaga Reformed Injili Indonesia, 2001), 10.

25 Philip Schaff, ed., Saint Agustinus's Anti Pelagian Works Volume 5 (Michigan: William B Eerdmans Publishing, 1997), 122. 


\section{Respon Manusia}

Manusia sebelum diselamatkan sudah mati dalam dosa sehingga tidak bisa memberikan respons terhadap keselamatan. Supaya manusia bisa memberikan respons maka dia harus terlebih dahulu dihidupkan oleh Roh Allah. Bandingkan dengan kisah Lazarus yang sudah mati di dalam kubur dan tidak dapat memberikan respon apapun dari suara orang yang berada di luar kubur. Ketika Yesus berkata "Lazarus keluarlah" seketika itu juga Lazarus hidup, lalu Lazarus bisa ke luar dari dalam kubur karena dia sudah dihidupkan oleh Yesus. Tanpa dihidupkan Yesus Lazarus tidak bisa keluar dari dalam kubur karena sudah mati. Respons manusia bukan penyebab dia selamat tetapi bukti bahwa dia telah dihidupkan oleh Roh Allah, ini adalah anugerah yang menyelamatkan. Respons adalah proklamasi kepada dunia bahwa dirinya sudah selamat, dan respons itu sendiri adalah anugerah karena Roh Kudus yang berkarya dalam keselamatan manusia (Kis. 16:14).

\section{Keselamatan}

Manusia sebelum diselamatkan sudah menerima bermacam bentuk anugerah dari Tuhan, anugerah umum (Mat. 5:45) dan anugerah khusus berupa hal-hal yang bersifat rohani, misalnya mendengar firman Tuhan sejak kecil, doa orangtua, khotbah, sakramen, lagu rohani, lingkungan rohani, dsb (2 Tim. 3:15). Manusia yang telah menerima bermacam anugerah dari Tuhan yang merupakan bentuk kemurahan hati Allah bekerja dan menuntun manusia supaya bertobat (Rm. 2:3-4). Keselamatan yang diterima oleh manusia bukan sebuah proses (sedikit demi sedikit) tetapi suatu peristiwa radikal karena intervensi Allah dalam hidupnya yang mengubahnya menjadi ciptaan baru dalam Kristus oleh Roh Kudus (kulminasi). Sebelum peristiwa ini terjadi (lahir baru) tidak bisa dipungkiri kalau manusia sudah menerima anugerah Allah dalam berbagai bentuk dan cara yang tidak terpahami seluruhnya secara nalar manusia yang mempersiapkan dan menuntun manusia kepada keselamatan. Anugerah yang menyelamatkan terjadi pada saat seseorang dilahirkan baru oleh Roh Kudus (Yoh. 3:5-7; Tit. $2: 11 ; 3: 5)$.

Luther, Calvin, dan Zwingli membangun doktrin teologi mereka berdasarkan "biblical concept" yang sangat kokoh dan komprehensif. Mereka melihat semua aspek kebenaran firman Tuhan dalam doktrin sola gratia. Mereka menyimpulkan bahwa "keselamatan dalam Kristus 100\% adalah anugerah, dan anugerah itu merupakan anugerah yang tak dapat ditolak oleh manusia." 26

\section{KESIMPULAN}

Sola gratia merupakan istilah yang diwahyukan Roh Kudus dalam Alkitab untuk menyatakan tiadanya andil manusia dalam keselamatan dirinya. Semua hal yang menyebabkan manusia diselamatkan adalah anugerah termasuk di dalamnya respons, percaya, kebebasan, kehendak, keputusan, dsb. Walaupun masih terdapat kelompok yang memberikan ruang bagi kehendak bebas manusia dalam menentukan keselamatannya, sebenarnya kehendak bebas manusia tidak berhubungan dengan kemampuan untuk menentukan keselamatannya.

Sola gratia menutup ruang bagi andil, jasa, kebaikan, respon, kehendak, dan kebebasan manusia. Sola gratia dinyatakan berulang-ulang dalam Alkitab supaya orang percaya menyadari bahwa dirinya diselamatkan dari kutuk dosa, perbudakan dosa, perbuatan dosa, penderitaan dosa, murka Allah yang akan datang, dan kematian yang kekal hanya berdasarkan kemurahan dan kebaikan Allah semata-mata.

Sola gratia mengingatkan orang percaya supaya selalu mengucap syukur kepada Allah Tritunggal yang menganugerahkan keselamatan secara cuma-cuma kepada mereka. Sola gratia mengingatkan kita bahwa “... segala sesuatu adalah dari Dia, dan oleh Dia, dan kepada Dia: Bagi Dialah kemuliaan sampai selama-lamanya!" (Rm.1:36). Sola gratia mengajak semua orang yang sudah diselamatkan melalui dan di dalam Kristus supaya bekerja keras di dalam anugerahNya untuk mengisi keselamatan yang sudah dialami dan sedang dinikmati supaya hasilnya

26 Yakub B. Susabda, Pengantar Ke Dalam Teologi Reformed (Surabaya: Lembaga Reformed Injili Indonesia, 1994), 37. 
maksimal sehingga tidak menjadi sia-sia (1 Kor. 15:10). Sola gratia mengingatkan orang percaya kepada The Shorter Catechism in Modern English a Baptist Version, Question 1 Q: "What is the chiefend of man?" A: "Man's chief end is to glorify God, and to enjoy him forever." 27

\section{REFERENSI}

Berthoud, Jean-Marc. "Luther and Erasmus: The Central Confrontation of the Reformation." Unio Cum Christo 3, no. 1 (April 1, 2017): 6581. https://uniocc.com/archive/luther-anderasmus.

Davis, Martin M. “T.F. Torrance: Union with Christ through the Communion of the Spirit." In die Skriflig/In Luce Verbi 51, no. 1 (2017): 1-9.

Eyo, Ubong Ekpenyong. "The Concept of Atonement in the Old Testament, GrecoRoman World and the New Testament." Journal of Humanities and Social Sciences 2, no. 2 (2020): 75-81.

Griffith, Howard. "Luther in 1520: Justification by Faith Alone." Reformed Faith \& Practice 3, no. 1 (2018):

28-37. https://journal.rts.edu/article/luther-in1520-justification-by-faith-alone/.

Hans Harmakaputra. "Grace, the Holy Spirit, and Love: Comparing the Thoughts of St. Agustine, Peter Lombard, and William of St. Thierry." Jurnal Teologi Reformed Indonesia 7, no. 1 (2017): 33-41.

Hoekema, Anthony A. Created in God's Image. Michigan: William B. Eermands Publishing Company, 1994.

III, Ben Witherington. The New Cambridge Bible Commentary. Edinburgh: Cambridge University Press, 2005.

Karl E. Hohmer. "Sola Gratia-Sola Fide-Sola Scriptura." Logia: A Journal of Lutheran Theology 27, no. 3 (2018): 19-22.

Merida, Toni. Christ-Centered Exposition Commentary. Nashville, Tennessee: B\&H Publishing Group, 2014.

Michael Stoltzfus. "Martin Luther: A Pure Doctrine of Faith." Journal of Lutheran Ethics 3, no. 1 (2003). https://www.elca.org/JLE/Articles/898.

Nicholes, Anna. "Diligence : Journal of the Liberty University Online Religion Capstone in Research and Scholarship The Foundation of

27 "The Shorter Catechism: A Baptist Version"

(Texas: Simpson Publishing Company, 2003), 3.
New Testament Canonicity" 1, no. September (2016).

O'Callaghan, Paul. "Luther and 'Sola Gratia': The Rapport Between Grace, Human Freedom, Good Works and Moral Life." Scripta Theologica 49, no. 1 (2017): 193-212. https://revistas.unav.edu/index.php/scripta -theologica/article/view/8750.

Paul, Robert S. The Atonement and the Sacraments: The Relation of the Atonement to the Sacraments of Baptism and the Lord's Supper. Nashville: Abingdong Press, 1960.

Schaff, Philip, ed. Saint Agustinus's Anti Pelagian Works Volume 5. Michigan: William B Eerdmans Publishing, 1997.

Sitanggang, Murni H. "Kehendak Bebas Manusia Menurut Augustine Dan Calvin Dalam Kaitannya Dengan Kedaulatan Allah." Jurnal Teologi Gracia Deo 1, no. 1 (2018): 32-45. http:/ / www.sttbaptisjkt.ac.id/ejournal/index.php/graciadeo/article/view/ 20.

Sodhiates, Spiros. The Hebrew-Greek Key Study Bible, New American Standard Version. Chattanooga: AMG Publishers, 1990.

Sukmadinata, Nana Syaodih. Metode Penelitian Pendidikan. Bandung: PT Remaja Rosdakarya, 2015.

Sulastio Hari. "Keselamatan Karena Kasih Karunia Menurut Efesus 2:1-10" 6, no. 1 (2020): 32-45. https://sttintheos.ac.id/ejournal/index.php/antusias/article/view/30 $7 / 178$.

Susabda, Yakub B. Pengantar Ke Dadalm Teologi Reformed. Surabaya: Lembaga Reformed Injili Indonesia, 2001.

- - -. Pengantar Ke Dalam Teologi Reformed. Surabaya: Lembaga Reformed Injili Indonesia, 1994.

Suwito, Gregorius Handoyo. “Karya Allah Dalam Menjamin Keselamatan Orang Percaya Dalam Perjanjian Baru." Teologi dan Pengembangan Pelayanan (2017): 16-43.

Ted Peters. "The Resistance of Self-Justification to God's Grace." Currents in Theology and Mission 46, no. 1 (2019): 58-68. http://currentsjournal.org/index.php/curre nts/article/view/166.

Williams, Garry J. "The Five Solas of the Reformation: Then and Now." Unio Cum Christo 3, no. 1 (April 1, 2017): 13. https:// uniocc.com/archive/47-the-fivesolas-of-the-reformation-then-and-now. 
Williamson, G. I. Pengakuan Iman Westminster. Surabaya: Penerbit Momentum, 2017.

"The Shorter Catechism: A Baptist Version." Texas: Simpson Publishing Company, 2003. 